\title{
Indications of Caesarean Section - Study of 100 cases in Mymensingh Medical College Hospital.
}

\author{
Khairun Nahar
}

\begin{abstract}
Summary
This study was a prospective descriptive one. It was done in MMCH from January 1996 to march 1996. A total of 714 deliveries occurred of which 225 deliveries by Caeserean section, incidence of LSCS was $30.36 \%$. The commonest age group of patients being operated ranged from 20 - 30 yrs (77\%). Most of the patients who had undergone LSCS were multigravida (45\%). The section were due to various indications, the commonest cause in this study was previous caesarean section, foetal distress and obstructed labour. The rate of primary section was more (84\%) while repeat section being $16 \%$. The peak range of operations were done in patients with 5 feet 2 inches height. The rate of elective operation was $37 \%$. where emergency operations were done in $63 \%$ of cases. Regarding foetal outcome. 92\% survived and $8 \%$ had perinatal death.
\end{abstract}

Key word: Caeserean section, indications.

\section{Introduction:}

Caeserean Section is a common operative procedure in obstetric practice throughout the world to ensure a healthy outcome of the mother \& newborn. With the advent of modern anesthesia, antibiotics and availability of blood transfusions the indications of this operation are being continually extended. Also with the implementation of modern technology in labour and neonatology unit the incidence of abdominal delivery has further raised to prevent potentially grave foetal and maternal morbidities. The rate of Caeserean delivery in the United States has quadrupled from 5\% of obstetric delivery in 1964 to more than 23\% in $1991^{1}$. The national C - section rate of Canada was $20 \%$ and Italy was $17.5 \%{ }^{2}$ At the present moment there is no comprehensive and extensive study in our country on the incidence of LSCS, though it is being increasingly employed in all hospitals and private clinics. Analysis of MIS data of DGHS from 12 Medical Collage Hospitals, 59 District Hospitals and 132 Upzilla Health Complexes (UHCs)-showed caesarean sections contributed $2.21 \%$ of all births taken place during the period of Jan-Dec $2007^{3}$. The present study was an effort to determine the incidence and evaluate its indications in the department of Obs \& Gynae in MMCH. This is a step to find out unnecessary indications of LSCS which may in future reduce the incidence rate in the country

Associate Surgeon (Gynae)

Shaheed Suhrawardy Medical College and Hospital

Sher-E-Bangla Nagar, Dhaka.

Correspondence:

Associate Surgeon (Gynae)

Shaheed Suhrawardy Medical College and Hospital

\section{Method of study:}

This prospective study was carried out in Mymensing Medical College Hospital, Department of Obs and Gynae from January 1996 to March 1996. Total 100 patients were randomly selected. After taking consent, detailed history was taken from all the cases, general and abdominal examination was done from date of admission up to the day of discharge. CPD (Cephalopelvic disproportion) was tested mainly by clinical pelvimetry. Labour patient was monitored by doing partogram. In elective cases- $\mathrm{Hb} \%$, Blood grouping \& Rh typing, urine R/E, USG of foetus done and in selected cases blood urea, s. creatinine, serum uric acid, SGPT and serum electrolyte done. In emergency cases, all investigations were not possible. Indication of LSCS detected antenatally and was compared with the findings at operation. Puerperal period upto the day of discharge was observed. $85 \%$ of patient operated by G/A \& 15\% patients by spinal anesthesia. Blood/Donor was kept ready in selected cases such as placenta previa \& repeat 2 LSCS cases.

\section{Results:}

A total of 741 deliveries occurred during the study period of which 516 deliveries were by vaginal \& 225 deliveries by LSCS. The rate of LSCS among all these deliveries was $30.36 \%$.

Indications of Caesarean Section - Study of 100 cases in Mymensingh Medical College Hospital. 


\section{Table-I:}

Age of patient who underwent LSCS $(n=100)$.

\begin{tabular}{|c|c|}
\hline Age group (yrs) & Percentage \\
\hline$<20$ & 7.0 \\
$20-25$ & 54.0 \\
$26-30$ & 23.0 \\
$31-35$ & 13.0 \\
$36-40$ & 3.0 \\
\hline
\end{tabular}

This table shows LSCS percentage maximum at age 20 -25 years age.

\section{Table-II:}

Incidence of LSCS in relation to height of the patients $(\mathrm{n}=100)$

\begin{tabular}{|l|l|}
\hline Height & Percentage \\
\hline 4' & 1.0 \\
4' 8" & 2.0 \\
4' 9" -4' 10" & 7.0 \\
4- i-|"-5' & 22.0 \\
5' 1" & 27.0 \\
5'2" & 28.0 \\
5' 3" & 10.0 \\
5' 4" & 2.0 \\
\hline
\end{tabular}

From the above data, $67 \%$ patient were above 5 feet in height. $33 \%$ patients were 5 feet or below.

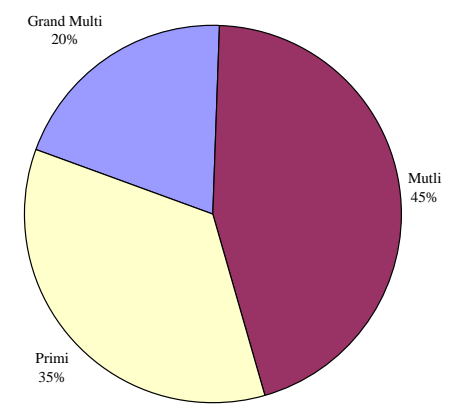

\section{Fig.I:}

Percentage of LSCS in relation to parity.
Table-III:

Indication of LSCS $(n=100)$

\begin{tabular}{|l|c|c|c|}
\hline Indications & Total & Primi & Multi \\
\hline Previous LSCS & 16 & 0 & 16 \\
Foetal distress & 15 & 9 & 6 \\
Obstructed labour & 14 & 8 & 6 \\
Failed progress of labour & & & \\
including failed induction & 10 & 7 & 3 \\
Pre-eclampsia & 9 & 6 & 3 \\
Bad obstetric history & 9 & 0 & 9 \\
Breech presentation & 6 & 3 & 3 \\
CPD (Cephalopelvic & & & \\
disproportion) & 6 & 4 & 2 \\
Transeverse lie & 4 & 2 & 2 \\
Placenta previa & 4 & 2 & 2 \\
Eclampsia & 3 & 3 & 0 \\
Face Presentation & 1 & 0 & 1 \\
Brow Presentation & 1 & 0 & 1 \\
Previous V.V.F repair & 1 & 0 & 1 \\
Cord prolapse & 1 & 1 & 0 \\
\hline
\end{tabular}

This table shows foetal distress \& obstructed labou were mainly responsible for LSCS in primigravida Previous LSCS was main indication in mulligravida Among all, previous H/O LSCS occupies the highes indication of LSCS.

Table-IV:

Nature of operations with indications $(n=100)$

\begin{tabular}{|l|c|c|}
\hline Indications & \multicolumn{2}{|c|}{ Nature of operation } \\
\hline & $\begin{array}{c}\text { Elective } \\
\text { no\% }\end{array}$ & $\begin{array}{c}\text { Emergency } \\
\text { no\% }\end{array}$ \\
\hline Previous LSCS & 13 & 3 \\
Foetal distress & 0 & 15 \\
Obstructed labour & 0 & 14 \\
Failed progress of labour & 0 & 10 \\
Pre-eclampsia & 3 & 6 \\
Bad obstetric history & 9 & 0 \\
Breech presentation & 6 & 0 \\
CPD & 2 & 4 \\
Transeverse lie & 2 & 2 \\
Placenta previa & 1 & 3 \\
Eclampsia & 0 & 3 \\
Face Presentation & 0 & 1 \\
Brow Presentation & 0 & 1 \\
Previous V.V.F repair & & \\
with term pregnancy & 1 & 0 \\
Cord prolapse & 0 & 63 \\
Total & 37 & \\
\hline
\end{tabular}

This table shows emergency LSCS was $63 \%$ and elective LSCS was 37\%. 


\section{Table-V:}

Comparison of primary \& repeat section $(n=100)$

\begin{tabular}{|l|c|}
\hline Caeserean Section & Percentage \\
\hline Primary & 84.0 \\
Repeat: Second & 14.0 \\
Third & 2.0 \\
\hline
\end{tabular}

This table shows the no. of primary section was more in relation to repeat section.

\section{Table-VI:}

Maternal complication of LSCS $(n=100)$

\begin{tabular}{|l|c|}
\hline Complications & Percentage \\
\hline Urinary Tract Infection & 14.0 \\
Wound infection & 11.0 \\
Wound dehiscence & 2.0 \\
Paralytic ileus & 7.0 \\
Postpartum hemorrhage & 4.0 \\
Chest infection \& cough & 3.0 \\
Vesico vaignal fistula & 2.0 \\
Thrombo embrolism & 0 \\
Maternal Death & 0 \\
\hline Total & 43.0 \\
\hline
\end{tabular}

This table shows urinary tract infection \& wound injection are two main morbidity in this study.

\section{Table-VII:}

Foetal out come of LSCS $(\mathrm{n}=100$

\begin{tabular}{|l|c|}
\hline Condition of baby & Percentage \\
\hline Healthy Asphyxiated IUGR & 69.017 .03 .0 \\
Pre-mature & 3.0 \\
Still born & 1.0 \\
Early neonatal death & 7.0 \\
\hline Total & 100 \\
\hline
\end{tabular}

In this study, one stillborn baby was delivered from patient of central placenta previa .

\section{Discussion:}

Caesarean section is used in cases in which vaginal delivery either is not feasible or would impose undue risk on mother or baby. Due to greater awareness of serious foetal distress \& avoidance of midforcep \& vaginal breech deliveries the rate of LSCS has steadily increased from (5\% to $20 \%)^{1}$

In Sir Salimullah Medical College and Mitford Hospital a rising trend of LSCS rates were noted from
$12.3 \%$ in 1984 to $28.15 \%$ in $1992^{4}$. In Mymensing Medical College Hospital ( $\mathrm{MMCH}$ ) a study carried out in 1988 where the incidence was noted as $25.79 \%$. In the present study incidence is about $30.36 \%$. Rising incidence can be explained by the fact that hospital receives a good number of high risk emergency cases with inadequate or no antenatal care Most of the patient brought late in labour after being handled by untrained birth attendants and are actually and potentially infected, often anemic and dehydarted. Early detection \& early decision also increase the incidence of LSCS.

Analysis of age of the patients showed that $77 \%$ of cases (table - I) were in the age group of maximum fertility i.e between 20 -30 years. A study in IPGMR showed $89 \%$ amongst this age group ${ }^{5}$. The study of Latin American hospital showed maximum incidence $>30$ years in primi patients, which might reflect delayed marriage in (western countries) ${ }^{6}$.

Short maternal height has been associated with an increased risk of CPD. Present study (Table - II) showed that $68 \%$ patients were $>5$ ' in height. Alam showed $76 \%$ patient $>5^{\prime}$ and Zaman showed $70 \%>5^{\prime}$ in their studies ${ }^{5,12}$. This may be explained by the fact that all the LSCS were not only due to CPD.

Study in IPGMR 1987, Sir Sallimullah Medical College (SSMC) \& Mitford Hospital 1992 showed higher incidence in multi ${ }^{4,5}$. Present study also corelates with it (Fig.I).

In the developed countries in the past decade indications of LSCS were breech presentation foetal distress, previous section \& dystocia ${ }^{11}$. in this study, common indications were previous section $16 \%$, foetal distress $15 \%$, obstructed labour $14 \%$, pre - eclampsia and eclampsia $12 \%$. Previous section constitute $20.41 \%$ in another study in our country ${ }^{4}$ Present study findings correlate with it.

Repeat sections constitute the commonest indication for LSCS in most other countries. It varies from 35\% of all LSCS in the USA to $23 \%$ in Norway, the lowest $18 \%$ being in Hungry ${ }^{7}$. The lowest rate in some indications of Caesarean Section - Study of 100 cases in Mymensingh Medical College Hospital.

Countries are due to lower primary section rate there and relatively higher rate of vaginal delivery after LSCS. In USA, previous LSCS emerges as a formidable and self-repeating cause of abdominal deliveries $^{8}$. The likelihood of vaginal birth appears to be independent of the indications for the previous LSCS (including CPD \& failure of progress of 
labour $)^{13}$.

In a study in IPGMR elective LSCS was 52\% and emergency LSCS was $48 \%{ }^{12}$. This was because patients due to previous operation or pregnancy associated complications, admitted in that institute for elective LSCS. There are high incidence of elective LSCS in western countries because of their sophisticated electronic foetal monitoring system ${ }^{8}$. Different studies from India showed incidence of emergency section was $82.7 \%$ and $85.92 \%{ }^{10}$. Study in SSMC \& Mitford Hospital findings of emergency LSCS was $69.71 \%$ and elective LSCS was $30.29 \%{ }^{4}$. This correlates with the present study, where emergency LSCS was 63\% and elective was 37\%. This may be explained by the fact that the patients were brought into hospital when crises arise, when traditional birth attendants failed to deliver them with utmost attempt.

In a study by Dawn and Chakrabarti at Eden Hospital, Kolkata, the incidence of morbidity was $37.5 \%$ and abdominal wound infection was major morbidity ${ }^{9}$.

Hammouda reported a maternal morbidity rate of $28.5 \%$ in the form of wound and urinary tract infection $\&$ there were no maternal deaths ${ }^{14}$. Present experience was similar to this observation.

0' Driscoll \& Foley found equally dramatic decrease in perinatal mortality (PNM) with active management of labour without any increase in the caesarean rate in Dublin $^{15}$. So we can reduce perinatal mortality without rising LSCS rate by risk screening in pregnancy, careful monitoring during labour and by immediate availability of specialized neonatal care.

\section{Conclusion}

In modern obstetrics, Caesarean section is a major surgical procedure for delivery. In spite of its low rate of maternal morbidity and mortality due to improved surgical technique and modern anesthetic skill, it still carries a slightly greater risk than normal vaginal delivery and risk is more in subsequent pregnancies. Those risks can be reduced by giving advice for a strict and regular antenatal check up during pregnancies to emphasize the need for an elective operation, if the indications are recurrent one. Though this study is not representative of whole population, the following comments can be made:

1. Regular antenatal check up should be done during pregnancy.

2. Birth attendants and other family welfare visitors should be trained adequately to detect and refer high risk cases to referral centre for proper management.

3. Improvement of transport system in the rural anc remote areas.

4. Accurate and early decision is to be taken ir performing LSCS to ensure healthy outcome.

5. Detailed critical review of all LSCS at morninc sessions should be done whether the indications were justified or not.

To reduce the post operative complications with LSCE some definite measures should be taken during anc after operation:

1. Catheterization should be avoided if possible \& i necessary, strict aseptic pre-caution must be taken tc prevent ascending infection .

2. All-out effort should be taken to implement infectior prevention.

3. Prophylactic antibiotic should be used in oui country as maintenance of optimum level of sterility because cleanliness may not be possible in majority of cases.

Caeserean section rate as recommended by WHO is 5\%$15 \%$ of total deliveries 16 . One should try to abide by the guidelines.

\section{References:}

1. Placek PJ. Taffel SM. Moien MC - Section rise; VBACS inch upwards. Am J Pub Health 1988; 78: 562 - 3.

2. Notzon FC, Plack PJ, Taffel SM. Comparison of national caesarean section rates. N Engl J Med 1987 : 316 :386 - 9.

3. Voice of MIS-Heath; Newsletter issue 4. May 2008, MIS-

H. DGHS, Dhaka, Bangladesh.

4. Chowdhury SB. Begum A. Indication and complication of caesarian section; a study of 1083 cases. Bangladesh J obstet Gynaecol 1994 ; 9, 1 - 7.

5. Zaman N. A clinical study on caesarian section in IPGMR ( dissertation). Dhaka. Bangladesh College of Physicians \& Surgeons; P 84-92.

6. Geen JE Meclean F, Usher SR. Caeserean section study of latin American Hospital . Am J obstet Gynaecol 1982; 142 .

7. Magnaun EF : Winchester Ml. Factors adversely affecting pregnancy outcome. Am J Perinatal $1995 ; 12: 464$.

8. Amrika H. Evan TN. Zone WB. Caeserean section : a 15 years review of changes in incidence of induction and risk : Am J obstet Gynaecol 1984 ; 104 , 81 -90.

9. Chakravorty DK. Dawn CS. Morbidity following Caeserean section. J Obstet Gynaecol India 1985 : 35 : 1037 10. Pardey JS. Jain M. Pandy LK Ten Years profile of caesarean section. J Obstet Gynaecol India 1986 :36: 448 Journal of Shaheed Suhrawardy Medical College

11. Panel and planning of the national consensus conference on aspects of casarean Birth. Indication for caesarean section : Final statement of the panel of the national consensus conference on aspects of caesesean birth. Can Med Asso J 1986 ; 134 ; 1342 - 52 
12. Alam ME, Study of indications of caesarean section in teaching hospital (dissertation). Dhaka. Bangladesh College of Physician and Surgeons ; 1994. P 80-89

13. Demianezuk N, Hunter JS, Taylor DW. Trial of labour after previous caesarean section. Am J Obstet Gynecol 1982; 142:640

14. Hammouda A A . Caeserean section in the young gravida. Am J obstet Gynaecol 1968 ; 100 ; 267 - 9
15. Driscoll K. Folley M. Correlation of decrease in perinatal mortality and increase in caeserean section rates. Obstet Gynaecol 1983 ; 61 ; 1 -5.

16. Current Obstetric and Gynaecologic Diagnosis \& Treatment. P 561, Edition 10. 